UDC: $159.923 .3: 959.947 .2$

DOI: https://doi.org/10.24195/2414-4665-2017-3-15

\author{
Oleksandr Sannikov, \\ Doctor of Psychology, senior researcher, associate professor, \\ Department of Theory and Methodology of Applied Psychology, \\ South Ukrainian National Pedagogical University named after K. D. Ushynsky, \\ 4, Fontanska Doroha Str., Odessa, Ukraine
}

\title{
CONCEPTUAL BASES OF RESEARCHING THE ISSUE OF MAKING DECISIONS BY A PERSONALITY
}

The paper aims to systematize and structure the approaches, concepts and theories of decision-making in psychology; define the principles of studying the choice of a personality; develop the psychological system of decision-making by a personality. The review of psycho-pedagogical, socio-philosophical and economic literature has made it possible to identify the approaches to the study of the phenomenon of "decision-making", its structure, mechanisms and factors that determine its effectiveness. The main ones are the following: strategic and style, normative approach, cognitive and target, regulatory and volitional, system and structural and subject and activity, providing the appropriate projection of the problem of choice of the personality. The insufficient development of the issue studied can be overcome by a deeper examination of the specifics of life decisions made by the personality. It seems productive to shift the focus of scientific interest from studying decision-making in the context of the activity to be performed to the personal context where the personality making life decisions becomes the object of research as well as the configuration of the psychological system, describing the features of the choice. The life decision is determinative at all stages of human existence, provides a constructive way out of various life situations, the formation and realization of the life path of the individual as a whole. The psychological system of making life decisions reflects the integrity of the personality which is formed by interrelated and complexly organized functional blocks and components. The structure of the properties forming the components of the system has a clearly expressed and stable character, retaining its characteristics within the type of life decision being made. Decisiveness is considered to be an integral characteristic of the personality, the ability to make mature life decisions easily and independently, selectively using personal resources.

Keywords: decision-making, choice of personality, personal approach to decision making, decision-making theory, psychological decision making system, concept of personality choice.

\section{Introduction}

The issue of making decisions by a personality has always been and remains relevant for scientists of different fields of knowledge. Psychology occupies one of the decisive places among them, since the decision-making as a subjective choice of a personality most clearly reveals his/her features, abilities and capabilities, influencing the change of different situations, forming an active life position, determining the optimal way of becoming a modern professional. Indeed, socio-cultural transformations in the society, on the one hand, require a personality to have a unique ability to make choices in extremely difficult conditions. These include the high responsibility for the choice, the need to take into account a number of factors, implicit and unstructured alternatives in the situations of high uncertainty, in terms of considerable emotional stress on the psyche, under conditions of time shortage, limited predictions of possible consequences, etc.

Rapid changes in social development of the society have exacerbated the problem of choice of the personality who makes a decision under conditions of instability of the society and whose activity is aimed at self-realization, selfactualization, development of himself/herself and the world around.

The scientific literature review has shown that the issue of decision-making is the research subject of psycholo- gy, pedagogy, philosophy, economics, mathematics and other sciences (R. L. Ackoff, A. Asmolov, F. E. Emery, G. Goldshtein, W. James, A. Karpov, S. Maddi, S. Maksimenko, P. Oschepkov, S. Plous, S. Rubinshtein, V. Shadrikov, A. Tversky, etc.). Nevertheless, there is a shortage of studies devoted to the analysis of existing conceptual approaches to understanding and explaining this phenomenon, as well as to a comprehensive definition and evaluation of choice and decision-making as integral characteristics of a personality.

The relevance of the development of the issue of decision-making by a personality is also caused by a purely scientific cognitive interest which is in the need to develop a concept of the personality that makes a life decision, to search for its psychological resources, determinants, and so on. If we take into account that the decision-making is of decisive importance for the organization of the behavior of the subject as a whole, for ensuring the effectiveness of individual and joint activities, the fundamental nature of this problem for modern psychology becomes understandable. The solution of a whole complex of both theoretical and applied psychological problems depends on the level of its development.

Decision making is considered as a stage of information processing in the system of purposeful human activity and is most generally defined as the formation and 
choice of actions and operations (R. L. Ackoff, A. Asmolov, F. E. Emery, G. Goldstein, W. James, A. Karpov, S. Maksimenko, P. Oschepkov, S. Rubinshtein, V. Shadrikov). Most often, decision making is described as overcoming uncertainty (M. Chumakova, M. Douglas, G. Herter, D. Kahneman, J. Kozielecki, R. Lipshitz, S. Maddi, V. Petrovsky, S. Plous, L. Podshivailova, P. Slovic, S. Smirnov, G. Solntseva, O. Strauss, A. Tversky, etc.); is studied in risk situations (I. Arendachuk, P. Bernstein, S. Bykova, A. Chebikin, N. Kogan, T. Kornilova, J. Kozielecki, A. Paramonov, O. Sannikova, Z. Shapira, O. Vdovichenko, M. Wallach, S. Yakovenko, E. Zharikov, etc.); is considered as a creative process (E. Kulchitskaya, V. Molyako); as a choice of a personality (G. Ball, A. Fam, Z. Kireeva, D. Leontiev, S. Maksimenko, E. Mandrikova, N. Naumova, O. Noskova, N. Pilipko, T. Titarenko, F. Vasilyuk, J. Virna, etc.). "Decision-making" is considered at the level of an integral mental process, as a kind of activity associated with the removal of the situation of uncertainty (K. AbulkhanovaSlavskaya, A. Adler, A. Bondarenko, A. Chebykin, N. Chepeleva, W. James, L. Karamushka, G. A. Kelly, K. Lewin, R. R. May, V. Molyako, V. Panok, N. Povyakel, N. Shevchenko, I. Zazyun, etc.).

The analysis of the issue of decision-making demonstrates the existence of theoretical differences in the understanding of such related concepts as "decision-making by the personality", "strategic decision-making", "decisionmaking style", "choice", "personal choice", "decisionmaking process", etc. which indicates the complexity and versatility of this phenomenon. The concept "decisionmaking" is also used in the field of philosophy, sociology, education, economics, mathematics, etc. which reveals its interdisciplinary character. At the same time, despite the significant relevance of this issue in the domestic (G. Ball, I. Bekh, V. Chernobrovkin, M. Grot, S. Maksimenko, V. Molyako, V. Panok, L. Pomytkina, V. Romenets, L. Sokhan, V. Tatenko) and foreign psychology (M. Bakhtin, A. Brushlinsky, A. Karpov, T. Kornilova, D. Leontiev, O. Tikhomirov, F. Vasilyuk), it still remains understudied.

The paper aims to review the scientific literature in the field of decision-making; systematize and structure the approaches, concepts and theories of decision-making in psychology; define the principles of studying the choice of a personality; develop the psychological system of decision-making by a personality.

\section{Research methods}

The theoretical analysis (practice-focused versions of system, differential and subject-activity approaches), as well as functional and information analysis of activity and synthesis of the leading psychological properties of the personality were used as the main research method. To obtain empirical regularities, the established system of psycho-diagnostic procedures of the research was used. It included methods helping to examine various indicators and characteristics of the phenomenon of decision-making; methods helping to reveal various personality traits hypothetically associated with the indicators of the phenomenon being studied and acting as its determinants and resources [11, p. 146].

Theories and concepts as the basis for a modern approach in the study of decision-making of the personality

The creation of psychological system of making decisions by a personality is based on domestic and foreign psychological theories, concepts and approaches to the analysis and description of the choice of a personality, including understanding the environment and the cycle of choice; evaluation of the choice of a personality as liferelated; personal action and motivation; choice as a conscious willful process; decision-making as an act of selfrealization of a personality, structure, mechanisms and criteria for decision-making by a personality.

1. The understanding of the decision-making environment is reflected in the K. Levin's Field Theory which has formed the methodology of analysis of the living space of a person and a group [6]. The life space includes many real and unreal, current, past and future events which form the individual's attitude towards them, and predetermines his/her behavior in a certain moment. It consists of various constructs (sectors, boundaries, locomotions, actions, valences) that affect the regulation of behavior and the choice of a person. In this formulation, assumptions caused by the specifics of making a life decision are possible.

First, such a selective focus of a person cannot be caused by the object itself, but is a characteristic of emotionality, its specific relation to any of the objects of interaction, the property of individuality. The acceptance of the valence of the objects, but not of the personality, regardless of the current situation of decision-making or the act of choice, is, in fact, simply a substitution of concepts.

The second oversight of the theory being analyzed is the assertion that at the moment of making a decision certain definite constructs (attitude, desires, dreams, plans and hopes, etc.) with positive valences, which will be attracted in a particular situation and determine person's behavior, can be the most important for the personality. In this case, we should assume that before making a decision the person's attitude towards any constructs is indifferent, and the personality exists, as it were, outside the psychological or living space.

Thirdly, the significance of the object for the personality after making a decision does not change its valence, but, for example, it can fade away simultaneously with the loss of interest in it. In fact, the object which is subjectively more related to the decision-making situation will be chosen. In this case, the decision-making is connected with the change of the psychological space itself, the structure of the situation after the decision is made.

2. "C-P-C" - the decision-making cycle proposed by D. Kelly includes circumspection (consideration, sequential consideration of several possible options); preemption (the choice of the most appropriate one at the moment, the best option for interpreting the situation (its biased evaluation) and control (actually the implementation and monitoring of the implementation of the chosen course of actions). As a result, all the elements of this cycle will lead to an expan- 
sion or definition of the system (C-P-C decision-making cycle): the suggestion of alternatives, the choice of the most constructive one, the execution of certain actions for its implementation [14].

For this study, it is important to concede the cyclicality at the stage of the analysis of the alternatives of making a life decision by a personality. In many respects the presence of cyclicality is caused by the attempts of the personality to identify and try those methods in the current situation, the use of which will provide the making of a life decision. The making of a choice is impossible until a person is sure that the analysis has been completed successfully and the only effective alternative for the given conditions has been chosen.

3. The issue of making life decisions by a personality is considered in the context of his/her life path, life creation, being studied by such scientists as G. Ball, I. Ermakov, V. Nechiporenko, V. Panok, D. Puzikov, L. Sohan, T. Titarenko, V. Yamnitsky, etc. Indeed, a person essentially depends on his/her past, both directly and indirectly influencing the present. Individual history reflected in the individual social experience of a personality, predetermines his/her attitude towards the future with his/her life prospects, plans and hopes, dreams and ways of achieving them. In G. Schwartz's view, “... decision-making is a conscious process, involving a preliminary clear understanding of the goal, structuring the initial problem situation, developing various options for choosing the best alternative and using the methods determined for this" $[13, \mathrm{p}$. 37]. L. Sokhan believes that life creation is a way of solving everyday medium-term and long-term (strategic) life tasks, and their solution is one of the most important areas of the life-creating activity of a personality. In this case, life fulfillment can be considered through the implementation of the mechanism for solving life problems. It means that every person has the right to take the risk of individual choice, making his/her own decisions and enriching his/her personal experience, without which life creation is impossible [12].

Summarizing, we should make two comments. First, the making of life decisions in the context of research studies on self-actualization, self-development and selfrealization of the personality requires considering its characteristics and their dynamics in various types of activity, various life situations. Secondly, life decisions are considered as global, strategically important, vital, reflecting profound transformations of the personality under conditions of continuous social-cultural changes in the environment for making and implementing decisions. This conclusion confirms one of the objective laws - all the elements of the life decision-making structure, its stages and connections in the situation of choice as well as the choice itself as a whole are controlled by the personality, and the choice and decision are always made only by the personality himself/herself.

4. Clarification of the specifics of the choice of personality was considered in the context of the philosophical and psychological category of the act by A. Asmolov,
M. Bakhtin, V. Petukhov, V. Romenetz, V. Stolin, F. Vasilyuk, V. Zinchenko and other scientists. The decision-making was also studied by V. Romenetz as a principle of personal act implementation. He believed that for the psychology of the "modern period" (the end of the $17^{\text {th }}$ the beginning of the $18^{\text {th }}$ century), self-cognition as selfdetermination, self-assertion of the personality, expressed in making appropriate decisions («soliloquia» according to A. Shaftesbury Ashley-Cooper) was the main human activity [8].

The mechanism of self-affirmation of a person in a situation is his/her motivation, the purpose of which is to overcome its conflictness and help in making a decision to act in a certain way. In other words, the motive is an active resource of the personality, and the decision-making allows $\mathrm{him} / \mathrm{her}$ to choose the ways for self-assertion and the actions which should be done for this.

5. A number of psychologists consider the choice as a form of volitional action. The origin, formation of volitional action and the structure of the volitional act were analyzed in the works of I. Bekh, V. Ivannikov, E. Ilin, V. Kalin, V. Selivanova, G. Tulchinsky, L. Vekker, L. Vygotsky, etc. In I. Bekh's opinion, making a decision by a personality is a conscious developed volitional process, in which he/she manifests the highest level of his/her activity, exhibits "intelligent will". The consciously made decision results in internal freedom experienced by a person [2].

We believe that complex volitional actions include the choice of one particular decision, realizing it with an action the purpose of which is to obtain the desired decision. The implementation of the volitional process when making a decision is considered to be a more correct action. It is the individual who controls the subjective unfolding of the "decision-making space", within which, if necessary, a volitional process is realized that is also determined by the person. In this case, the will acts in relation to decisionmaking as a person's resource, the use of which ensures the overcoming of barriers, the removal of contradictions, and the elimination of difficulties.

6. An example of a correct formalization of the ratio of risk and uncertainty in decision-making process is the "Theory of Prospects" by Amos Tversky and Daniel Kahneman which makes it possible to explain the personality's behavior and decision-making mechanisms in terms of values and probabilities [15]. The authors showed that when making decisions people consider not the objective, but the subjective probability and the significance of the decision, creating a number of effects of a departure from strict rationality. "The effect of uncertainty" is the people's overestimation of the single-valued outcomes in comparison with the highly probable ones, and the "reflection effect" illustrates the opposition - the personality's preferences when replacing the word "win" with "losing" in the task. The latter is called "the reflection effect" and shows that most people avoid risk in assessing the situation as a probable win and strive for it in order to assess a possible loss. 
We believe that the preference for a specific solution is directly influenced by the way the problem has been formed in the person's mind.

7. The overcoming of the existing methodological discrepancies in the research of "technological" decisionmaking strategies and analytical methods in problem solving became possible due to the allocation of the functionallevel regulation of decision-making being implemented in the intellectual decisions studies by T. V. Kornilova involving both the variability of functional structures and the multiplicity of connections between various processes mediating the choice of a personality [5].

It should be noted that the regulation of the choice and making of life decisions is determined not only by the conditions specified by the situation of choice, but also by the intellectual potential of a person, his/her cognitive resource that integrates cognitive efforts and social experience along with other regulatory components.

Study principles of the personality's choice

A personality is distinguished by a unique ability to make life decisions under extremely difficult conditions. These include the high responsibility for the result and the consideration of many difficultly comparable selection criteria, the generation of implicit, poorly structured alternatives and time deficit, high uncertainty of the consequences of choice and significant emotional stress on the psyche, hardly predicted cost of possible consequences, etc. Such a specific role of a personality making a decision required the development of an original conceptual approach that allows describing the phenomenon under consideration, its structure, topology and typology, the features of manifestation in the forms of the personality's activity.

The concept of making life decisions by a personality is based on the methodological principles that define both the boundaries of its existence and the rules of construction. As a methodological foundation of the concept, the principles of system and structure, activity and uncertainty, development and transformation, reality and determinism, unity of methodology, theory and experiment have been selected.

The use of the system-structural approach makes it possible to investigate, according to P. Anokhin's figurative expression, "the patterns of interaction and assistance of individual components of the system aimed at obtaining a programmed result", that is, to study the internal operational architecture of the system [1]. Target analysis, related to the system as a whole and to its individual components, as well as the study of the target integrity make it possible to disclose the component composition of the system of "making life decisions by a personality" and the interconnection of its individual components forming this system, to form the idea of the structure of the system, its internal organization and levels [3].

The principle of activity involves understanding mental reflection as an active process. It is based on a postulate which proves that a personality must be self-sufficient and active [7]. The decision-making is considered by us as a manifestation of the activity of a personality, and not a passive respond to the circumstances. Without denying the important role of situational (environmental, social) and personal factors in the formation of alternatives and the making of a life decision, it is necessary to take into account the activity of a personality which can manifest itself in different attitudes towards these factors, in the potential possibility of regulating the life decision by the personality making it.

The reality principle means that the making of a life decision by a personality is carried out in a situation where he/she makes a comparison of several reality projections (real and virtual and their multiple combinations). The principle of determinism involves a causal conditioning of the choice of a person who makes decisions under the influence of both external and internal factors (which are not even always realized), interacting with each other.

The principle of uncertainty. A personality makes decisions in a situation when the strategy of achieving the goal is not determined in advance and therefore the results of the choice of alternatives can lead to different decisions. Uncertainty is associated with the variability and uniqueness of both the conditions and acts of choice and the actions for their implementation. Their assessment as well as aresult and consequences of implementing the final decision are not known in advance. Examining the uncertainty, the researchers emphasize the fact that decision-making is also necessary because the conditions of uncertainty are determined existentially (not to mention the differences between its objective and subjective representations). The essence of human existence is the constant overcoming of the uncertainty, "unaccountability" of any forms and bases of one's decisions and actions [5].

The principle of development involves the study of mental processes and personality properties from the point of view of their regular changes [7]. The principle of transformation in the context of choice is based on person's act (choice, decision-making and fulfillment of implementation actions) capable of changing the life situation emerged. Life is the result of countless choices, rejections of unrealizable alternatives, wrong and incorrect decisions. Changes in the personality's life are the reflection of the adoption of a set of decisions, each of which becomes the basis and the opportunity for the next life path of the personality in the space-time, the basis of self-improvement, transformation. The principle of the unity of methodology, theory and experiment in the context of the research makes it possible to verify theoretical assumptions (about the structure, components of decision-making by the personality, causal dependencies, functions, determinants) by means of the empirical study, the goal of which is either confirmation or refutation of hypotheses [11, p. 85-89].

Structure of the psychological system of making life decisions by the personality

The concepts, approaches, and principles of investigating the choice of a personality, singled out by means of the theoretical analysis, have made it possible to determine the configuration and structure of the "psychological sys- 
tem of making life decisions by a personality". We consider the following postulates to be the basic ones:

A process of making decisions by a personality is, first of all, a personal choice out of possible alternative variants determined by the psychological organization of the personality, involving multi-leveled characteristics and at the same time reflecting his/her integrity. The making of a life decision is a specific vital manifestation of the activity of the personality, choosing the best possible option, or subjectively perceived as such to resolve the life situation. We believe that "life decisions", as a result and a product of the psychological system, are the system of organizing and regulating the life activity, in the center of which is the person who makes a life decision and responsibility for it. The system of life decisions is constantly developing, changing, is being organized and regulated, which makes the regulatory component of the system of life decisions the core, supporting and system-forming.

The achievement of the goal (a life decision), as well as the interaction of the goal and decision-making resources are carried out through a decision-making mechanism within a certain life situation. The mechanism for making a life decision is the activation of resources and their interrelations that ensure the attainment of a life goal decision making, the subjective and functional productivity of the personality in a real or virtual life situation. The key elements of life decision-making mechanism functioning are the following: logical sequence of its implementation; work with resources (selection and updating); overcoming barriers and difficulties in making decisions; reconstruction of life situation, multi-criteria evaluation of elements; selecting regulatory components; inclusion of social components (social systems, conditions) in which decisions are made and the mechanism is implemented [9].

The structure of the system of making life decisions is formed by the following three functional blocks with specific characteristics: a) a block of personal components; b) a block of components of interaction with the environment; c) a block of components of determination.

The first one, the block of personal components, includes the totality of personality properties that provide "the acceptance of a life situation", the promotion of solutions, the choice and making of a life decision. The block of personal components of the system of making life decision is formed by volitional, emotional, cognitive, motivational and social experience components. Together they provide resources for making a life decision.

The second one, the block of components of the interaction of the individual with the environment, includes the personality properties that ensure the development of the strategy and the actions of the personality to implement the decision taken and to assess the prognosis of the consequences of its implementation. The block of components of interaction with the environment in the system of making a life decision by the personality carries out the organization and control of the implementation of the choice, the evaluation of its consequences and includes the operational and resulting components.
The third one, the block of determination components, includes the personality properties that ensure the management of the making of a productive life decision by the personality. The component of determination carries out the management and regulation of decision-making and is represented by a component of the orientation (attitude) to make a life decision, reasonableness (wisdom) in making a life decision, steadiness (stability) and ergicity (activity) in making a life decision. Decisiveness as a regulatory subsystem of making a life decision coordinates the functioning of personal components, components of interaction with the environment; ensures the inclusion of the individual in the system of interaction with the environment, support and regulation of decision-making; coordinates the selection, updating and management of the resources necessary for the personality to make a life decision [10].

Testing the efficiency of the functional blocks of the system and the functions they carry out, performed with the help of a system of psycho-diagnostic procedures of research has confirmed the universal nature of the psychological system, its stability and reliability of results in relation to real and virtual situations of life choices and decisionmaking by the personality.

\section{Conclusions}

The review of psycho-pedagogical, sociophilosophical and economic literature has made it possible to identify the approaches to the study of the phenomenon of "decision-making", its structure, mechanisms and factors that determine its effectiveness. The main ones are the following: strategic and style, normative approach, cognitive and target, regulatory and volitional, system and structural and subject and activity, providing the appropriate projection of the problem of choice of the personality.

The insufficient development of the issue studied can be overcome by a deeper examination of the specifics of life decisions made by the personality. It seems productive to shift the focus of scientific interest from studying decision-making in the context of the activity to be performed to the personal context where the personality making life decisions becomes the object of research as well as the configuration of the psychological system, describing the features of its choice. The life decision is determinative at all stages of human existence, provides a constructive way out of various life situations, the formation and realization of the life path of the individual as a whole.

The psychological system of making life decisions reflects the integrity of the personality which is formed by interrelated and complexly organized functional blocks and components. The structure of the properties forming the components of the system has a clearly expressed and stable character, retaining its characteristics within the type of life decision being made.

Decisiveness is considered to be an integral characteristic of the personality, the ability to make mature life decisions easily and independently, selectively using personal resources. 


\section{REFERENCES}

1. Anokhin, P. K. (1978). Filosofskie aspekty teorii funktsionalnykh sistem [Philosophical aspects of the theory of functional systems]. Mosow: Nauka [in Russian].

2. Bekh, I. D. (1995). Vid voli do osobystosti [From the will to the personality]. Kyiv: Ukraina-Vita [in Ukrainian].

3. Ganzen, V. A. (1984). Sistemnye opisaniya $v$ psikhologii [System descriptions in psychology]. Leningrad: Izd-vo Leningr. un-ta [in Russian].

4. Kondratenko, Yu. P. (2006). Optymizatsiia protsesiv pryiniattia rishen $v$ umovakh nevyznachenosti [Optimization of decision making under conditions of uncertainty]. Mykolaiv: Vyd-vo MDGhU im. Petra Moghyly [in Ukrainian].

5. Kornilova, T. V. (2003). Psikhologiya riska $i$ prinyatiya resheniy [Psychology of risk and decisionmaking]. Moscow: Aspect Press [in Russian].

6. Levin, K. (2001). Dinamicheskaia psikhologiya [Dynamic Psychology]. E. Patiaeva, D. Leontev (Transl.). Moscow: Smysl [in Russian].

7. Maksymenko, S. D. (2008). Zahalna psykholohiia [General Psychology]. Kyiv: Tsentr uchbovoi literatury [in Ukrainian].

8. Romenets, V. A. (1990). Istoriia psykholohii XVII stolittia [History of Psychology of the $17^{\text {th }}$ century]. Kyiv: Vyshha shkola [in Ukrainian].

9. Sannikov, A. I. (2016). Psikhologicheskie mekhanizmy zhiznennogo vybora lichnosti [Psychological mechanisms of making a choice by a personality]. Nauka i osvita - Science and education, 11, 91-97 [in Russian].

\section{ЛИТЕРАТУРА}

1. Анохин П.К. Философские аспекты теории функциональных систем: [избр. труды] / П. К. Анохин. - М. : Наука, 1978. - 400 с.

2. Бех І. Д. Від волі до особистості / І. Д. Бех. К. : Україна-Віта, 1995. - 202 с.

3. Ганзен В. А. Системные описания в психологии / В. А. Ганзен. - Л. : Изд-во Ленингр. ун-та, 1984. $-176 \mathrm{c}$.

4. Кондратенко Ю. П. Оптимізація процесів прийняття рішень в умовах невизначеності: [Навч. посіб. для студ. ВНЗ] / Ю. П. Кондратенко; Миколаївський держ. гуманіт. ун-т ім. Петра Могили комплексу Києво-Могилянська академія. - Миколаїв : Вид-во МДГУ ім. Петра Могили, 2006. - 96 с.

5. Корнилова Т. В. Психология риска и принятия решений: учебное пособие для вузов / Т. В. Корнилова. - М. : Аспект Пресс, 2003. - 286 с.

6. Левин К. Динамическая психология: Избр. тр. / К. Левин; Пер. с нем. и англ. Е. Патяевой, Д. Леонтьева. - М. : Смысл, 2001. - 568 с.

7. Максименко С. Д. Загальна психологія: Навчальний посібник / С. Д. Максименко; Вид. 3-є, перероб. та допов. - К. : Центр учбової літератури, 2008. $272 \mathrm{c}$.
10. Sannikov, A. I. (2016). «Reshimost» i «reshitelnost» V psikhologicheskoi sisteme priniatiia lichnostiu zhiznennykh reshenii ["Decisiveness" and "resolution" in the psychological system of making everyday decisions by a personality]. Teoretychni i prykladni problemy psykholohii - Theoretical and applied problems of psychology: Collected Works of East Ukrainian National University of Vladimir Dal (Vol. 1(39), (pp. 201213). Severodonetsk [in Russian].

11. Sannikov, A. I. (2015). Psikhologiya zhiznennogo vybora lichnosti: Monografiya [Psychology of life choices of a personality: monograph]. Odessa: Izd-vo VMV [in Russian].

12. Sokhan, L. V. (2010). Iskusstvo zhiznetvorchestva. Prednaznachenie. Zhiznetvorchestvo. Sudba: Sotsiologicheskie ocherki, sotsialno-psikhologicheskie esse, interviu, glossarii [The Art of Life Creation. Purpose. Life-making. Fate: Sociological essays, sociopsychological essays, interviews, glossary]. Kiev: Izdat. Dom Dmitriia Burago [in Russian].

13. Shvarts, G. M. (1997). Psikhologiia individualnykh reshenii [Psychology of individual solutions]. Moscow: Firma «Promysel»; Izd-vo AO «Dialog-MGU» [in Russian].

14. Kelly, G. A. (1955). The psychology of personal constructs. A theory of personality. (Vol. 1). New York: Norton [in English].

15. Kahneman, D. \& Tversky, A. (1979). Prospect Theory: An Analysis of Decision under Risk. Econometrica, 47(2), 263-291 [in English].

8. Роменець В. А. Історія психології XVII століття [Текст]: навч. посіб. / В. А. Роменець. - К. : Вища школа, 1990. - 368 с.

9. Санников А. И. Психологические механизмы жизненного выбора личности / А. И. Санников // Наука і освіта. - 2016. - № 11/CXXXXXII. - С. 91-97.

10. Санников А. И. «Решимость» и «решительность» в психологической системе принятия личностью жизненных решений / А. И. Санников // Теоретичні і прикладні проблеми психології: збірник наукових праць Східноукраїнського національного університету імені Володимира Даля. - Сєверодонецьк, 2016. - № 1 (39). - С. 201-213.

11. Санников А. И. Психология жизненного выбора личности: Монография / А. И. Санников. Одесса : Изд-во ВМВ, 2015. - 440 с.

12. Сохань Л. В. Искусство жизнетворчества. Предназначение. Жизнетворчество. Судьба: Социологические очерки, социально-психологические эссе, интервью, глоссарий / Л. В. Сохань. - К. : Издат. Дом Дмитрия Бураго, 2010. - 576 с.

13. Шварц Г. М. Психология индивидуальных решений / Г. М. Шварц. - М. : Фирма «Промысел»; Изд-во АО «Диалог-МГУ», 1997. - 180 с.

14. Kelly G. A. The psychology of personal con- 
structs. A theory of personality. Vol. 1. New York: Norton, 1955. Pp. 526-565.

15. Kahneman, D. \& Tversky, A. Prospect Theory:
An Analysis of Decision under Risk // Econometrica. 1979. 47(2). Pp. 263-291.

\section{Олександр Ілліч Санніков, \\ доктор психологічних наук, старший науковий співробітник, доцент кафедри теорії та методики практичної психологї, Південноукраїнський національний педагогічний університет імені К. Д. Уиинського, вул. Фонтанська дорога, 4, м. Одеса, Украӥна}

\section{КОНЦЕПТУАЛЬНІ ОСНОВИ ДОСЛІДЖЕНЬ ПРИЙНЯТТЯ РІШЕНЬ ОСОБИСТІСТЮ}

У статті показано різноманітність існуючих поглядів на проблематику прийняття рішень у психології, філософії, педагогіці, економіці, математиці тощо. Встановлено, що вивчення прийняття рішень особистістю в основному відбувається шляхом аналізу дій і операцій з його реалізації, особливостей подолання невизначеності в ситуації вибору, специфіки вибору як творчого процесу, як виду діяльності особистості. Виділено теоретичні розбіжності вчених в існуючих концепціях, підходах і моделях, у презентації структури й типології прийняття рішень, його характеристик. Показано, що вимагає систематизації й упорядкування використання таких родинних понять, як прийняття рішень особистістю, вибір, діяльність прийняття рішень, стратегія життєвого вибору тощо. Представлено результати аналізу вітчизняних і закордонних психологічних підходів до вивчення вибору особистості, що слугують теоретико-методологічними основами концепції психологічної системи прийняття рішень особистістю. Означена система включає: розуміння середовища й життєвого простору; цикл вибору й прийняття рішення; оцінку вибору в контексті життєвого шляху особистості; розгляд прийняття рішення через категорію особистісного вчинку й мотивації; вибір як свідомий вольовий процес; прийняття рішення як акт самореалізації особистості, механізми й критерії прийняття рішень особистістю. Розглянуто переваги особистісного підходу, що дозволяють інтегрувати відомості, отримані в різних теоретичних розробках, у єдину систему. Виділено принципи, які утворюють методологічну базу сучасної концепції прийняття життєвих рішень, границі їі існування й правила конфігурування. Установлено, що розробка концепції прийняття особистістю життєвих рішень дозволяє інтегрувати існуючі наукові погляди щодо проблематики вибору й прийняття рішень у єдину психологічну систему організації й регуляції життєдіяльності особистості. Доведено, що основним механізмом прийняття життєвого рішення $є$ активація ресурсів особистості та їх взаємозв'язків, що забезпечують вибір особистості, суб’єктивну й функціональну корисність в умовах реальної або віртуальної життєвої ситуації. Представлена структура психологічної системи прийняття особистістю життєвого рішення включає три функціональні блоки: блок особистісних компонентів, блок взаємодії із середовищем і блок компонентів рішимості. Визначено функції, реалізовані кожним блоком психологічної системи вибору, виявлено роль рішимості особистості в керуванні прийняттям продуктивного рішення. Рішимість розуміється як багатокомпонентна цілісна властивість особистості, здатність сміливо й незалежно приймати зрілі життєві рішення, вибірково використовуючи при цьому особистісні ресурси. Встановлено, що прийняття життєвого рішення - це специфічний, життєво важливий прояв активності особистості, що здійснює вибір варіанта, найкращого 3 можливих, або суб'єктивно сприйнятих особистістю як таких для вирішення життєвої ситуації.

Ключові слова: прийняття рішення, вибір особистості, особистісний підхід до прийняття рішення, теорії прийняття рішень, психологічна система прийняття життєвих рішень, концепція вибору особистості.

Submitted on February, 24, 2017 